\title{
Insurance Premium And Economic Performance In Nigeria: A Variance Decomposition Approach
}

\author{
Peter C. Uruakpa \\ Department of Banking \& Finance, \\ Abia State University, Uturu, Nigeria
}

\begin{abstract}
This study assessed insurance premium and Nigeria's economic performance. It aimed at finding out the relationship insurance premium, investment and assets have with Nigeria's GDP. Descriptive statistics, Augmented Dickey Fuller Unit Root Test, Johansen cointegration, OLS regression, variance decomposition and granger causality tests were adopted. Findings revealed that all the series are significant and but not normally distributed. The correlation matrix shows that there is high and positive correlation between the independent variables. The results of the unit root tests using Augmented Dickey-Fuller test show that all the variables do not have unit roots (that is, are stationary) at $5 \%$ in their first differences. The Johansen co-integration result confirms that there is long run relationship between insurance activities and economic growth in Nigeria. The OLS result suggests that 93.11 percent of the total variation found in GDP is explained by the presence of total assets, investments and premium of the insurance industry sector while the F-Statistics has a value of $\mathbf{1 6 3 . 1 0 8 0}$ which is highly significant at $\mathbf{5 \%}$ confidence level implying that insurance industry play significant role in development of the Nigerian economy. The Variance Decomposition for 10 period indicates that Insurance sector investment is more significant than premium for most of the periods. However, since premium represents revenue for the insurance industry it has positive impact on GDP for all the periods while GDP responds positively. This granger causality result shows that there is granger causality relationship between insurance premium, investment and assets have granger causality with GDP. From the findings, it recommends that insurance business authorities should review its reform policy and ensure that policies that will strengthen premium mobilization in Nigeria are put in place. Insurance companies need to invest more of their funds in productive sectors of the economy.
\end{abstract}

Keywords: Insurance, Insurance premium, Risk, GDP, Investment

\section{INTRODUCTION}

The insurance industry is a highly specialized industry that gives greater security to the fortunes of common people and among the whole society. It is one of the financial institutions in Nigeria today that aid economic development and growth (Victor, 2013). Chikeleze and Echekoba (2008), define insurance as a contract whereby one party, called the insurer, in return for a consideration, called the premium, undertakes to pay the other party, called the insured a sum of money or its equivalent in kind upon the happening of specified event that is contrary to the interest of the insured. Obasi (2010) opines that "by entering into the contract, the insurance company agrees to pay the policy holder or his family members a predetermined sum of money in case of any unfortunate event for a predetermined fixed sum payable which is in normal term called insurance premiums". The types of insurance products available in Nigeria include, motor insurance; general accident insurance; fire insurance; marine, aviation and transit insurance; life insurance; oil and gas insurance; health insurance; among others. In general terms, insurance business involve the transfer of risk from one individual to another, and the pooling of funds from the insured (policy holders) in order to pay for relatively uncommon but severely devastating losses which can occur to the insured (Ajayi, 2000; 
Augustine and Nwanneka, 2011; Gollier, 2003). This group, known as insurance company, must increase its hold on the premium and widen its profit margin to cope with the demand of their customer. Insurance premium is the fixed amount of money paid by the insured to the insurance company regularly. Insurance company collects premium to provide security for the purpose.

It has been argued by Pandey (2003) that while the main sources of working capital for commercial banks remain customer deposits and the major outlet is loans and advances, Solomon (2018) suggested that the main source of working capital for insurance companies is premium and major outlet is investment of such premium in long term investments. Insurance companies are the second biggest financial institutions in the mobilization of savings after banking institutions. The savings they mobilize through premium are invested in various financial instruments and businesses to make returns which are then used to compensate the insured's loss when it arises. Insurance companies are the basic components of financial institution, which encourages and mobilizes savings and channel savings into productive investment because of their numerous offices. Hence, insurance companies hold assets in government securities, stock, shares and bonds, mortgages and loans, cash and bills receivable and miscellaneous items (Aderibigbe, 2004). The investment objectives of insurance companies are mainly safety, liquidity and growth. Akpan and Joseph (2017) noted that these objectives which form the framework of investment portfolio structure of these firms are based on the nature of liabilities of the insurance firms, their operational focus and guidelines of the industry regulators which vary from one country to another and the stages of development in the various countries. In view of the investment practices and of portfolio insurance companies, Ahmed (2012) describes them as creator of wealth and mobilizer of funds for economic growth.

Modern insurance in Nigeria dates back to the 1960's and since then more insurance companies have sprung up. Insurance company's strength lies in the fact that huge amounts come by way of premiums. Every premium represents a risk that is covered by that premium, in effect, therefore, these vast amounts represent pooling of risks, the funds are collected and held in trust for the benefit of the policy holders. The management of Insurance companies is required to keep this aspect in mind and make all it decision in ways that benefit the community. This applies also to its investment. This is why successful insurance companies would not be found investing in speculative ventured as their investment benefit the society it large (Anchanvinay, 2010). According to Nigerian Insurance Report (2010), recapitalization of the insurance industry in Nigeria has no doubt recorded a huge volume of business, for instance, the sector was able to pull an aggregate gross premium income of $\$ 90,000$ million in 2007 , over $18 \%$ more than was obtained in 2005. Growth in premium maintained an upward trend of $25 \%$ in 2008 and $30 \%$ in 2009 . Insurance density stood at $6.9 \%$, industry global ranking was 61 and the gross premium income was $\$ 180,000$ million in 2008 (NAICOM, 2010). A recent CBN (2017) report shows the industry delivered 1,837,822.4 million in Gross Premium in 2016 and 2129810.5536 million in 2017. This represented increased insurance penetration from $6 \%$ in 2008 to $56 \%$ in 2017, growth in insurance contribution to GDP from $0.7 \%$ in 2008 to $1.6 \%$ and $1.87 \%$ in 2016 and 2017 respectively, and growth in insurance density from $\$ 1,200$ per individual in 2008 to about $\$ 9,400$ in 2017 . Thus a further assessment into the insurance premium and economic performance provides the thrust for this study.

\section{Statement of the Problem}

Since the post SAP era, numerous insurance companies have sprung up. However their relevance and impact on the growth of the economy have been questioned. This is due to various reasons such as loss of focus on their traditional function of insuring risk and paying 
indemnity to loss thus leading to loss of confidence on the part of the customers on the industry. Furthermore, premium mobilized are invested in non-productive sector such as the stock market while less are invested in the preferred sectors such agriculture, manufacturing, mining etc. Empirical studies on the contribution of insurance premium to Nigeria's economic growth have provided mix results. Studies by Oke, 2012; Solomon (2018); Ukpong \& Acha (2017) indicate a positive relationship while Akpan and Joseph (2017); Torbira \& Ogbulu (2013) provided a contrary report. It is pertinent therefore, to determine the true effect of insurance premium on Nigeria economy using current data.

\section{Objectives of the Study}

The aim of this study is to assess insurance premium and economic performance in Nigeria. Other specific objectives are:

1. To assess the impact of the insurance premium on Nigeria's GDP.

2. To determine the relationship between investment of insurance industry and Nigeria's GDP.

3. To evaluate the depth of impact insurance assets on GDP in Nigeria.

\section{Research Hypotheses}

The following research hypotheses have been constructed to provide a bearing for the study.

Ho1: Insurance premium has no significant impact on Nigeria's GDP.

Ho$_{2}$ : There is no significant relationship between investment of insurance industry and Nigeria's GDP.

Ho $_{3}$ : There is no positive and significant level of depth in insurance industry's asset to impact on GDP in Nigeria

\section{REVIEW OF RELATED LITERATURE}

Insurance: Dickson (1960) in Oke (2012) opined that insurance is designed to protect the financial wellbeing of an individual, company or other entity in case of unexpected loss. According to him, some forms of insurance are required by law; while others are optional. Agreeing to the terms of an insurance policy creates a contract between the insurer and the insured. Gollier (2003) argued that insurance involved the transfer of risk from one individual to another, sharing losses on an equitable basis by all members of the group. The group, known as insurance company, must increase its hold on the premium and widen its profit margin to cope with the demand of their customer.

Insurance Premium: Insurance is designed to protect the financial well-being of an individual, company or other entity in the case of unexpected loss. In exchange for payments from the insured (called premiums), the insurer agrees to pay the policy holder a sum of money upon the occurrence of a specific event. In most cases, the policy holder pays part of the loss (called the deductible), and the insurer pays the rest (Victor, 2013). Brainard (2008) see insurance premium as the indemnification and risk pooling properties of insurance to facilitate commercial transactions and the provision of credit by mitigating losses as well as the measurement and management of non diversifiable risk more generally. Typically insurance contracts involve small periodic payments in return for protection against uncertain, but potentially severe losses. Among other things, this income smoothing effect helps to avoid excessive and costly bankruptcies and facilitates lending to businesses.

\section{Functions of Insurance}

According to Aneke (2004) when insurance is viewed from various forms of its classification, it is always easy to appreciate the social and economic importance of insurance. 
i. A Risk Transfer and Loss Sharing Mechanism: In this regard, the function of insurance is in two fold. One is that it is a mechanism for transferring a risk from one individual to a group. The other is sharing losses on some recognized equitable basis by all the members of the group. It is an economic device that creates a subsidy by the many who are subject to a certain risk, to the few, who are affected by the occurrence of the risk. It makes the financial consequences of the risk fall lightly on many than falling heavily on few.

ii. A Social and Welfare Device: By compensating a victim of an accidental misfortune, the insurance industry is promoting individual and corporate happiness and a healthy society.

iii. Encourages Business Pursuit and Stability: Insurance has been described as the "handmaiden of commerce and industry" and the only business which exist in order to ensure the survival of all other business. Purchase of insurance product promotes confidence and eliminates insecurity and fear of loss. Without the protection offered by insurance to other businesses, the modern economic system, which we operate today, would almost certainly grind to a halt; reduction of the risk of business venture ensures a better psychological frame of mind to enable the entrepreneur concentrate and devote his skill to the improvement of his business for the benefit of the whole economy.

iv. Insurance Offers Indemnification against Unexpected Loss: Insurance stands as a guaranteed source of funds when the availability of other sources fail as a result of the loss. Adequately protected, business need not to face the grim prospects of liquidation, following a loss. Also a business entity can be continued without interruption even though the key person or sole proprietor dies.

v. Insurance Helps to Mobilize Idle Capital for Investment in the Economy: On the fear of losing their investment, many investors tie up a substantial amount of capital in idle reserve. The effect of insurance in this regard is to mobilize these funds and release them for the development of trade and industry which would probably not have place in the absence of insurance.

\section{Insurance and Premium}

Insurance taking is the agreement where, for a stipulated payment called the premium one party (the insurer) agrees to pay to the other (the policy holder or his designated beneficiary) amount (the claim payment or benefit) upon the occurrence of a specific loss. The defined claim payment amount can be a fixed amount or can reimburse all or part of the loss that occurred. The insurer consider the losses expect for the insurance pool and the potential for variation in order to charge premium that, in total will be sufficient to cover all of the projected claim payment for the insurance pool. The premium charged to each of the pool participants is that participant's share of the total premium for the pool. Each premium may be adjusted to reflect any special characteristics of the particular policy (Anderson \& Brown, 2005). Normally, only a small percentage of policy holders suffer losses. Their losses are paid out of the premiums collected from the pool of policy holders. Thus, the entire pool compensates the unfortunate few. Each policy holder exchanges an unknown loss for the payment of a known premium. According to Anderson and Brown (2005) under the formal arrangement the party agreeing to make claims payments is insurance company or the insurer. The pool participant is the policy holder. The payments that the policy holder makes to the insurer are premiums. The insurance contract is the policy. The rise of any unanticipated losses is transferred from the policy holder for the insurer who has the right to specify the rules and conditions for participating in the insurance pool. They stated further that the insurer may restrict the particular kinds of losses covered. For example a peril is a potential cause of a loss. Perils may include fires, hurricanes, theft and heart attack. The insurance policy may define specific perils that are covered, or it may cover all perils with certain named exclusions (for example, loss as a 
result of war or loss of life due to suicide). Hazards are conditions that increase the probability or expected magnitude of a loss. Examples include smoking when considering losses due to fires, or a California residence when considering earthquake damage. In summary, an insurance contract covers a policy holder for economic loss caused by a peril named in the policy. The policy holder pays a known premium to have the insurer guarantee payment for the unknown loss. This manner, the policy holder transfers the economic risk to the insurance company. Risk which can be insured by private companies typically share seven common characteristics:

Since insurance operates through pooling resources, the majority of insurance policies are provided for individual members of large classes allowing insurers to benefit from the law of large numbers in which predicted losses are similar to the actual losses. Exceptional includes. Lloyd's of London which is famous for insuring the life or health of actors, sports, figures and other famous individuals. However, all exposures will have particular differences, which may lead to different premium rates. Definite loss- The loss takes place at a known time, in a known place and from a known cause. The classic example is death of an insured person in a life insurance policy. Ideally the time, place and cause of a loss should be clear enough that a reasonable person, with sufficient information could objectively verify all the three elements. Accident loss- The event that constitutes the trigger of a claim should be fortuitous or at least outside the control of the beneficiary of the insurance. The loss should be pure in the sense that it results from an event for which there is only the opportunity for loss. Large loss-The size of the loss must be meaningful from the perspective of the insured. Insurance premiums need to cover both the expected cost of losses, plus the cost of issuing and administrating the policy, adjusting losses, and supplying the capital need to reasonably assure that the insurer will be able to pay claims for small losses; those latter costs may be several times the size of the expected cost of losses. There is hardly any point in paying such costs unless the protection offered has really value to a buyer. Calculable Loss- There are two elements that must be at least estimable, if not formally calculable the probability of loss and the attendant cost. Probability of loss is generally an empirical exercise, while cost has more to-do with the ability of a reasonable person in possession of a copy of the insurance policy and a proof of loss associated with acclaim presented under that policy to make a reasonably definite and objective evaluation of the amount of the loss recoverable as a result of the claim. Affordable Premiums- If the likelihood of an insured event is too high, or the cost of the event is so large that the resulting premium is large relative to the amount of protection offered, it is not likely that the insurance will be purchased, even if on offer. Further as the accounting standards, the premium cannot be so large that there is not a reasonable chance of a significant loss to the insurer if there is no such insurance, but not the substance.

\section{THEORETICAL FRAMEWORK}

This study is premised on financial intermediation theory. The theory is based on studies establishing the relationship that exists between financial intermediation and economic growth by Schumpeter (1934), Goldsmith (1969), McKinnon (1973) and Shaw (1973). In the same vein, Greenwood and Jovanovich (1990) observed that financial development can lead to rapid growth. In a related study, Bencivenga and Smith (1991) explained that development of financial institutions such as insurance companies and efficient financial intermediation contributes to economic growth by channeling savings to high productive activities and reduction of liquidity risks. They therefore concluded that financial intermediation leads to growth. Insurance companies, in particular, facilitate a nation's innumerable economic transactions through efficient and effective savings mobilization, risk transfer and indemnification, and financial intermediation processes (Salvatore, 2013; Mishkin, 2010). By mobilizing long-term savings, these companies provide financial security to the nation's 
citizens. Further, they enhance the government's accumulation of productive capital, which is primarily invested in long term investment instruments that can be used for infrastructural development. As the dominant segment in the insurance market, the sustainability of the life insurance business is crucial for developing nations. They play active role as the country's protection and repair system (Sambasivam \& Ayele 2013). Literature have thus reported that five possible relationships could exist between insurance and economic growth: negative (Zouhaier, 2014), demand following (Ching, Kogid, \& Furuoka, 2010), supply leading (Ward \& Zurbruegg, 2000), interdependence (Ghosh, 2013) and no relationship at all (Haiss \& Sumegi, 2008; Omoke, 2012). This theory thus provides us the foundation to find out how insurance has contributed to Nigeria's economic growth since they are the second largest financial institution after banks in Nigeria.

\section{Review of Empirical Studies}

Adamu, Okorafor and Adeyemi (2011) studied the influence of economic factors on business operations of some randomly selected Insurance Companies. The deposit base of five selected Insurance Companies was used as a measure of business performance. The impact of economic factors such as Average exchange rate movement, average minimum rediscount rate, rate of growth of GDP and average inflation rate on deposit base of five Insurance Companies was examined. Multivariate regression and ANOVA were used to analyze the data collected and test the hypothesis formulated. It was discovered that economic environment significantly affects the performance of Insurance Companies.

Mojekwu, Agwuegbo and Olowokudejo (2011) examined the impact of insurance contributions on economic growth in Nigeria over a twenty seven year period, between 1981 and 2008 using a dynamic factor model. The technique described a number of methods designed to analyze a functional relationship between the volume of insurance contribution and economic growth in terms of underlying but unobservable random quantities called factors. The factor loadings indicate which common trend is related to which set of time series. The result obtained through this approach shows that the functional relationship between the volume of insurance contribution and economic growth in Nigeria is a first order vector autoregressive model.

Oke (2012) used fixed effect model and co-integration analysis to determine the short-run and long-run relationship between insurance sector growth and economic development in Nigeria. The study spanned from the period 1986 to 2009. The result reveals that insurance sector growth and development positively and significantly affects economic growth. The result of the granger causality test indicates that the extent of influence the insurance sector growth had on economic growth was limited and not direct because of some cultural, attitudinal traits and values in the economy.

Omoke (2011) empirically examined insurance market activities in Nigeria with the view to determining its impact on economic growth. The period of study was 1970-2008, the study made use of insurance density measures (premium per capita) as a measure for insurance market activity and real GDP for economic growth. The Johansen cointegration and vector error correction approach was used to estimate the relationship between the variables. All the variables used were stationary at first difference and the result showed a long term relationship existing among the variables. The finding of this study is that the insurance sector did not reveal any positively and significant affect on economic growth in Nigeria within the period of study. The result shows a low insurance market activity in Nigeria and that Nigerians have not fully embraced the insurance industry despite its importance to the growth of the economy. 
Eze and Okoye (2013) explored the impact of insurance practice on the growth of Nigerian economy. Insurance premium income, total insurance investment and income of insurance development was used as determinants of insurance practice. They employed unit root tests, Johansen co-integration test and error correction model in data analysis and to determine the short and long run effect of the model. The study observed that the insurance premium capital has significantly impacted on economic growth in Nigeria; that the level of total insurance investment has significantly effected on economic growth in Nigeria; and that there is causal relationship between insurance sector development and economic growth in Nigeria. The implication of these findings is that insurance industry would contribute meaningful to the growth of Nigeria economy in long run. The study concludes that there is a significant positive effect of insurance practice on the growth of Nigerian economy.

Victor (2013) focused on the "Impact of Insurance on Economic Growth In Nigeria". To achieve this, models were formulated and data for the period 1998-2007 were collated while the cointegration and Error Correction model were employed for analysis. The findings towed the direction of the alternate hypotheses which state that; there is a significant relationship between insurance premium and economic growth. Based on the study, it is recommended that policy efforts should be directed by government at growing the insurance industry in the country; and through such means enhances investment as well as production and employment creation.

Chang, Lee, and Chang (2014) again examined the relationship between insurance and economic growth for 10 OECD. They apply bootstrapping Granger causality model over a period of 1979-2006. They revealed that one-way Granger causality running from all insurance activities to economic growth for France, Japan, Netherlands, Switzerland and the UK. Furthermore, economic growth Granger causes insurance activities in Canada (for life insurance), Italy (for total and life insurance) and the US (for total and non-life insurance). There is a two-way Granger causality between life insurance activity and economic growth in the US, while no causality between insurance activities and economic growth is found in Belgium (for all insurance), Canada (for total and non-life insurance), Italy (for non-life insurance) and Sweden (for life insurance).

Din, Abu-Bakar and Regupathi (2017) carried out a study to answer the question on whether insurance promote economic growth. It aimed at examining the relationship between insurance and economic growth in 20 countries for the period 2006-2015. The Hausman statistics confirmed that fixed effect model is appropriate for this data-set. This study found a positive and a significant relationship between life insurance, measured through net written premiums and density, and economic growth for developed countries while the same is true for developing countries when insurance is measured through penetration proxy. The results also reveal that non-life insurance has statistically significant, for all three proxies, relationship with economic growth for developing countries whereas, in case of developed countries, the results are only significant when insurance density is used as a proxy for insurance. Moreover, the role of non-life insurance is more significant for developing countries as compared to developed countries.

Similarly, Akpan and Joseph (2017) empirically and comparatively analyzed the insurance companies and commercials banks' investment portfolios and their contributions to economic growth in Nigeria. The study covers the period from 1996 to 2011. The secondary data collected for the study were presented in tables and graphs. A multiple linear regression method was adopted to test the research hypotheses. An ex-post facto research design was 
adopted in the study. The findings were that there is a positive but no significant relationship between government securities, stock of bond, real estate and mortgage, policy and other loans, cash deposits, bills of exchange of insurance companies and economic growth in Nigeria. This implies that investment portfolios of insurance companies do not contribute significantly to economic growth in Nigeria within the period under study. Also, there is a significant relationship between ordinary shares, preference shares, debentures, subsidiaries, other investments, total investments of commercial banks and economic growth in Nigeria. This implies that investment portfolios of commercial banks do contribute significantly to economic growth in Nigeria within the period under study.

A recent study by Din, Angappan, \& Baker (2017) investigated the relationship between insurance and economic growth for USA, UK, China, India, Malaysia and Pakistan using Pooled Mean Group (PMG/ARDL). They reported a positive and significant relationship between aggregate insurance, measured by net premiums and economic growth for all six countries. In addition, at disaggregate level; non-life insurance is also significantly associated with economic growth for all six countries. However, life insurance is only promoting economic growth for UK, India and Pakistan while the reverse is true for USA, China and Malaysia.

Ukpong and Acha (2017) evaluated the co-integration and causal relationship between insurance and economic development in Nigeria using time series data from 1990 - 2013. Gross domestic product (GDP) is adopted as a proxy for the level of economic development, while total life insurance premiums (TPL), total non-life insurance premiums (TPNL) and total insurance investment (TII) are used in measuring growth in the insurance sector. Data is operationalized through the stationarity test, co-integration test, regression analysis and granger causality tests. The stationarity test reveals that all-time series data are stationary at the $1 \%, 5 \%$ and $10 \%$ levels of significance. The test for co-integration shows that all cointegrate when GDP is the endogenous variable. The granger causality test reveals that there is a bidirectional relationship existing between GDP and total non-life insurance premiums while a unidirectional relationship exists between GDP and total life insurance premiums with no causal relationship existing between GDP and total insurance investments. It concluded that insurance not only contributes to economic development but also has a long term equilibrium relationship.

Solomon (2018) empirically studied the impact of insurance premium and investment on economic performance in Nigeria. The study covers the period 1981-2017. It made use of data collected from CBN Statistical Bulletin while regression statistical tool was applied. It was found that insurance premium and asset have positive and significant relationship with GDP. The result showed that there is negative relationship between investment of insurance industry and GDP.

\section{Research Design and Sources of Data}

\section{RESEARCH METHODOLOGY}

The study will make use of quasi experimental research design. This is used because the study is based on time series events and also intends to investigate the strength of relationship between two or more economic factors on which design is based. The study relied heavily on CBN Statistical Bulletin. The data sourced include: Gross Domestic Product (GDP), insurance companies' premium, investment, shareholder capital and assets from 1986 to 2017.

\section{Model Specification}

The model to be that adopted in this research is the OLS multiple regression approach since all the independent variables are indicators of fiscal policy and therefore explained in one model. 
The variables

$$
\mathrm{GDP}=\mathrm{F}(\mathrm{PREM}, \mathrm{INVT}, \text { and ASST })
$$

Where:

GDP $=$ Gross Domestic Product

$\mathrm{PRE}=$ Insurance premium

$\mathrm{INV}=$ Investment

CAP $=$ Capital

$\mathrm{AST}=$ Asset

Where:

$$
\mathrm{GDP}_{\mathrm{t}}=\mathrm{b}_{0}+\mathrm{b}_{1} \mathrm{PREM}_{\mathrm{t}}+\mathrm{b}_{2} \mathrm{INVT}_{\mathrm{t}}+\mathrm{b}_{3} \mathrm{ASST}_{\mathrm{t}}+\mathrm{U}_{1 \mathrm{t}} \ldots
$$

$b_{1}, b_{2}, b_{3}$, and $b_{4}$, are parameter estimates for PREM, INVT and ASST respectively.

$\mathrm{U}_{1 \mathrm{t}}=$ Error terms

$\mathrm{b}_{0}=$ intercept of GDP $\mathrm{t}$ model

$\mathrm{t}=$ number of years

\section{Method of Data Analysis}

This study will adopt the unit root test, ordinary least square, co-integration and variance decomposition techniques to estimate the models.

\section{DATA ANALYSIS AND INTERPRETATION}

Table 1: Descriptive Analysis

\begin{tabular}{|l|c|c|c|c|}
\hline & GDP & PREM & INVT & ASST \\
\hline Mean & 22665724 & 81315.82 & 90646.50 & 919806.3 \\
\hline Median & 4679212. & 14597.28 & 21583.46 & 50131.65 \\
\hline Maximum & $1.14 \mathrm{E}+08$ & 400687.2 & 547982.9 & 7515351. \\
\hline Minimum & 94325.02 & 191.8000 & 145.4530 & 1014.250 \\
\hline Std. Dev. & 34203449 & 120622.9 & 134469.1 & 1930343. \\
\hline Skewness & 1.480101 & 1.592876 & 1.742839 & 2.207838 \\
\hline Kurtosis & 3.699564 & 4.241880 & 5.423753 & 6.631333 \\
\hline Jarque-Bera & 14.26378 & 18.02406 & 27.78781 & 50.38903 \\
\hline Probability & 0.000799 & 0.000122 & 0.000001 & 0.000000 \\
\hline Observations & 37 & 37 & 37 & 37 \\
\hline \multicolumn{5}{|c|}{ Source: Eviews 8 }
\end{tabular}

In the descriptive statistics testing the stability of variables in the model as shown in table 1, GDP has a mean value of 22665724 and a standard deviation of 34203449 , PREM has a mean value of 81315.82 and a standard deviation of 120622.9 , INVT has a mean value of 919806.3 and a standard deviation value of 134469.1, ASST has a mean value of 6.457429 and a standard deviation value of 1930343. The Jarque-Bera statistic to test the normality of the variables shows that GDP has a prob.value of 0.000799, PREM with prob.value of 0.000122 , for INVT with prob.value of 0.00001 and for ASST with prob.value of 0.000000 . This indicates that all the series are significant and but not normally distributed. All the employed variables have 37 data point observations and the data set is a long term data. 
Table 2: Correlation Matrix

\begin{tabular}{|c|c|c|c|c|}
\hline & GDP & PREM & INVT & ASST \\
\hline GDP & 1.000000 & 0.950762 & 0.787278 & 0.934555 \\
\hline PREM & 0.950762 & 1.000000 & 0.812826 & 0.900200 \\
\hline INVT & 0.787278 & 0.812826 & 1.000000 & 0.787328 \\
\hline ASST & 0.934555 & 0.900200 & 0.787328 & 1.000000 \\
\hline
\end{tabular}

\section{Source: Eviews}

The correlation matrix depicted in table 2 shows that the least collinearity value is 0.787278 while the highest collinearity value is 0.950762 . This indicates there is high and positive correlation between the variables.

Table 3: Stationarity Test for Variables

\begin{tabular}{|l|l|c|c|}
\hline \multirow{2}{*}{ Variables } & \multicolumn{2}{|c|}{ ADF Test } & \\
\hline & At Level 1(0) & First Difference 1(1) & Order of Integration \\
\hline GDP & -1.423572 & -3.669565 & $1(1)$ \\
\hline PREM & -7.085336 & -11.40942 & $1(1)$ \\
\hline INVT & -2.888557 & -2.794705 & $1(1)$ \\
\hline ASST & -2.499541 & -3.785321 & $1(1)$ \\
\hline \multirow{2}{*}{ Critical values 1\% } & -3.769597 & -3.632900 & $1(1)$ \\
\cline { 2 - 4 } & -3.004861 & -2.948404 & $1(1)$ \\
\cline { 2 - 4 } & -2.642242 & -2.612874 & \\
\hline
\end{tabular}

\section{Source: Eviews}

The results of the unit root tests using Augmented Dickey-Fuller test to determine whether they are stationary or non-stationary series. The two tests are employed to reinforce one another, to ensure their robustness and boost confidence in their reliability. The results shows that all the variables do not have unit roots (that is, are stationary) at $5 \%$ in their first differences. Thus, variables are said to be integrated in the order of 1(1). Moreover, having observed that all the variables for the study is stationary, we, therefore, proceed to test for actual number of cointegration equations that exist among the series.

Table 4: Johansen Co-integration

\begin{tabular}{|c|c|c|c|c|}
\hline \multicolumn{4}{|c|}{ Trend assumption: Linear deterministic trend } & \\
\hline \multicolumn{4}{|c|}{ Series: GDP PREM INVT ASST } & \\
\hline \multicolumn{4}{|c|}{ Unrestricted Cointegration Rank Test (Trace) } & \\
\hline Hypothesized & & Trace & 0.05 & \\
\hline No. of CE(s) & Eigenvalue & Statistic & Critical Value & Prob.** \\
\hline None & 0.979659 & 236.4897 & 47.85613 & 0.0001 \\
\hline At most $1 *$ & 0.862921 & 100.1606 & 29.79707 & 0.0001 \\
\hline At most 2 & 0.516385 & 30.60854 & 15.49471 & 0.0001 \\
\hline At most 3 & 0.137624 & 5.182226 & 3.841466 & 0.5000 \\
\hline \multicolumn{5}{|c|}{ Trace test indicates 4 cointegrating eqn(s) at the 0.05 level } \\
\hline \multicolumn{5}{|c|}{$*$ denotes rejection of the hypothesis at the 0.05 level } \\
\hline \multicolumn{5}{|c|}{ Unrestricted Cointegration Rank Test (Maximum Eigenvalue) } \\
\hline Hypothesized & & Max-Eigen & 0.05 & \\
\hline No. of CE(s) & Eigenvalue & Statistic & Critical Value & Prob. ${ }^{* *}$ \\
\hline None & 0.979659 & 136.3291 & 47.85613 & 0.0001 \\
\hline At most 1 & 0.862921 & 69.55203 & 29.79707 & 0.0001 \\
\hline At most 2 & 0.516385 & 25.42632 & 15.49471 & 0.0001 \\
\hline At most 3 & 0.137624 & 5.182226 & 3.841466 & 0.5000 \\
\hline \multicolumn{5}{|c|}{ Max-eigenvalue test indicates 4 cointegrating eqn(s) at the 0.05 level } \\
\hline \multicolumn{5}{|c|}{$*$ denotes rejection of the hypothesis at the 0.05 level } \\
\hline
\end{tabular}

\section{Source: Eviews 8}


The Johansen co-integration result in Table 4 used to test the existence of long run relationship among the variables showed that for the Unrestricted Co-integration Rank Test, there is four cointegrating equation which suggests that insurance premium, asset and investment have long run relationship with GDP. The Maximum Eigenvalue indicates that there are four cointegrating equations among the variables in the model. This confirms that there is long run relationship between insurance activities and economic growth in Nigeria.

Table 5 OLS Regression Analysis

\begin{tabular}{|c|c|c|c|c|}
\hline \multicolumn{5}{|c|}{ Dependent Variable: GDP } \\
\hline \multicolumn{5}{|l|}{ Method: Least Squares } \\
\hline \multicolumn{5}{|c|}{ Date: $08 / 21 / 18$ Time: 08:28 } \\
\hline \multicolumn{5}{|l|}{ Sample: 19812017} \\
\hline \multicolumn{5}{|c|}{ Included observations: 37} \\
\hline Variable & Coefficient & Std. Error & t-Statistic & Prob. \\
\hline $\mathrm{C}$ & 2742942. & 1893452. & 1.448646 & 0.1569 \\
\hline PREM & 167.8374 & 30.90739 & 5.430334 & 0.0000 \\
\hline INVT & -6.774952 & 19.58286 & -0.345963 & 0.7316 \\
\hline ASST & 7.489695 & 1.824739 & 4.104528 & 0.0002 \\
\hline R-squared & 0.936821 & & & \\
\hline Adjusted R-squared & 0.931077 & & & \\
\hline Durbin-Watson stat & 1.943354 & & & \\
\hline F-statistic & 163.1080 & & & \\
\hline Prob(F-statistic) & 0.000000 & & & \\
\hline
\end{tabular}

Source: Eviews 8

The model shows a coefficient of determination $\left(\mathrm{R}^{2}\right)$ is $93.68 \%$. This indicates a goodness of fit on the regression line, that is, the variables are strongly fitted. The adjusted coefficient of correlation $\left(\mathrm{R}^{-2}\right)$ found to be $93.11 \%$. It implies that 93.11 percent of the total variation found in GDP is explained by the presence of total assets, investments and premium of the insurance industry sector.

From the model, the result showed that there is positive relationship between insurance premium and GDP. That is, the higher the insurance premium, the higher the GDP which conforms to expectation. It suggests that a unit rise in premium leads to 167.8374 units rise in GDP. Given the t-Statistics value of 5.430334 and a prob value of $0.0000<0.05$ confidence level, Insurance premium has significant impact on Nigeria's GDP.

The result showed that there is negative relationship between investment of insurance industry and GDP. That is, the higher the insurance premium, the lower the GDP which does not conform to expectation. It suggests that a unit rise in investment of insurance industry leads to 6.774952units decrease in GDP.

There is positive relationship between insurance industry's asset and GDP. That is, the higher the insurance industry's asset, the higher the GDP which conforms to expectation. It suggests that a unit rise in investment of insurance industry leads to 7.489695 units increase in GDP.

The F-Statistics has a value of 163.1080 which is highly significant at $5 \%$ confidence level implying that insurance industry play significant role in development of the Nigerian economy. 
Table 6 Autoregressive Conditional Heteroskedasticity Analysis Heteroskedasticity Test: ARCH

\begin{tabular}{|c|c|c|c|c|}
\hline $\begin{array}{l}\text { F-statistic } \\
\text { Obs*R-squared }\end{array}$ & $\begin{array}{l}12.55474 \\
9.708372\end{array}$ & \multicolumn{2}{|c|}{$\begin{array}{l}\text { Prob. F(1,34) } \\
\text { Prob. Chi-Square(1) }\end{array}$} & $\begin{array}{l}0.0012 \\
0.0018\end{array}$ \\
\hline \multicolumn{5}{|l|}{ Test Equation: } \\
\hline \multicolumn{5}{|c|}{ Dependent Variable: RESID^2 } \\
\hline \multicolumn{5}{|l|}{ Method: Least Squares } \\
\hline \multicolumn{5}{|c|}{ Date: $12 / 26 / 18$ Time: $16: 18$} \\
\hline \multicolumn{5}{|c|}{ Sample (adjusted): 19822017} \\
\hline \multicolumn{5}{|c|}{ Included observations: 36 after adjustments } \\
\hline Variable & Coefficient & Std. Error & t-Statistic & Prob. \\
\hline $\mathrm{C}$ & $3.65 \mathrm{E}+13$ & $2.92 \mathrm{E}+13$ & 1.249022 & 0.2202 \\
\hline $\operatorname{RESID}^{\wedge} 2(-1)$ & 0.518422 & 0.146312 & 3.543267 & 0.0012 \\
\hline R-squared & 0.269677 & & & \\
\hline Adjusted R-squared & 0.248197 & & & \\
\hline Durbin-Watson stat & 2.277159 & & & \\
\hline F-statistic & 12.55474 & & & \\
\hline Prob(F-statistic) & 0.001172 & & & \\
\hline
\end{tabular}

\section{Source: Eviews 8}

Results of robustness tests reveal that the model selection criterion suggest that the ARCH model proves to be superior to the OLS because it records significantly higher Durbin Watson value of 2.277159 as against 1.943354 for OLS. The residual is highly significant at $5 \%$ confidence level. The F-statistics at 12.55474 further supports the earlier findings that there is significant impact of insurance industry on economic growth in Nigeria. 
Table 7a: Variance decomposition: Cholesky Ordering: GDP PREM INVT ASST

\begin{tabular}{|c|c|c|c|c|c|}
\hline \multicolumn{6}{|c|}{ Variance Decomposition of GDP: } \\
\hline Period & S.E. & GDP & PREM & INVT & ASST \\
\hline 1 & 2148971. & 100.0000 & 0.000000 & 0.000000 & 0.000000 \\
\hline 2 & 2503006. & 73.72609 & 3.875494 & 5.676579 & 16.72183 \\
\hline 3 & 3462720. & 53.96602 & 13.06465 & 23.64930 & 9.320039 \\
\hline 4 & 4310733. & 63.72192 & 12.88267 & 15.48247 & 7.912939 \\
\hline 5 & 5282299. & 68.19282 & 9.847128 & 15.64675 & 6.313306 \\
\hline 6 & 6842933. & 45.53039 & 15.91025 & 30.85912 & 7.700244 \\
\hline 7 & 8958031. & 30.20403 & 21.37076 & 41.03231 & 7.392903 \\
\hline 8 & 11271988 & 20.20768 & 25.94680 & 46.35312 & 7.492394 \\
\hline 9 & 13406250 & 14.84025 & 28.69708 & 48.60632 & 7.856347 \\
\hline 10 & 15254750 & 12.12779 & 30.01229 & 49.50584 & 8.354080 \\
\hline \multicolumn{6}{|c|}{ Variance Decomposition of PREM: } \\
\hline Period & S.E. & GDP & PREM & INVT & ASST \\
\hline 1 & 17687.58 & 41.16169 & 58.83831 & 0.000000 & 0.000000 \\
\hline 2 & 27081.34 & 29.50338 & 35.84520 & 17.64370 & 17.00772 \\
\hline 3 & 34148.93 & 46.63513 & 23.50926 & 13.68717 & 16.16844 \\
\hline 4 & 41991.85 & 46.33193 & 18.72351 & 15.50335 & 19.44122 \\
\hline 5 & 46770.69 & 55.55544 & 15.09704 & 13.61588 & 15.73163 \\
\hline 6 & 50167.17 & 48.58000 & 18.00105 & 18.70279 & 14.71616 \\
\hline 7 & 54083.03 & 41.80959 & 20.65830 & 23.45385 & 14.07826 \\
\hline 8 & 58057.18 & 37.39294 & 21.49920 & 27.73844 & 13.36942 \\
\hline 9 & 62097.11 & 33.26483 & 23.45467 & 30.56299 & 12.71751 \\
\hline 10 & 66223.83 & 29.47095 & 24.72371 & 33.04320 & 12.76214 \\
\hline \multicolumn{6}{|c|}{ Variance Decomposition of INVT: } \\
\hline Period & S.E. & GDP & PREM & INVT & ASST \\
\hline 1 & 34466.74 & 19.58421 & 22.80422 & 57.61157 & 0.000000 \\
\hline 2 & 63319.92 & 6.096511 & 30.07029 & 62.29342 & 1.539781 \\
\hline 3 & 82882.46 & 6.331937 & 36.27445 & 55.35156 & 2.042060 \\
\hline 4 & 91697.96 & 7.605736 & 36.03404 & 53.30489 & 3.055334 \\
\hline 5 & 92920.97 & 7.422152 & 36.45202 & 52.96210 & 3.163730 \\
\hline 6 & 93210.32 & 7.515450 & 36.41978 & 52.64155 & 3.423218 \\
\hline 7 & 93620.35 & 7.788759 & 36.23732 & 52.46649 & 3.507432 \\
\hline 8 & 94575.40 & 9.136113 & 35.72901 & 51.61185 & 3.523024 \\
\hline 9 & 95530.80 & 10.71665 & 35.01855 & 50.61084 & 3.653961 \\
\hline 10 & 97420.69 & 12.31593 & 33.99749 & 49.74056 & 3.946027 \\
\hline \multicolumn{6}{|c|}{ Variance Decomposition of ASST: } \\
\hline Period & S.E. & GDP & PREM & INVT & ASST \\
\hline 1 & 206600.9 & 27.46610 & 27.06956 & 19.72563 & 25.73871 \\
\hline 2 & 282900.0 & 44.75269 & 29.04803 & 12.15555 & 14.04373 \\
\hline 3 & 301176.9 & 49.21765 & 26.54737 & 11.77480 & 12.46019 \\
\hline 4 & 336509.4 & 39.82248 & 22.24128 & 27.94971 & 9.986532 \\
\hline 5 & 408620.7 & 27.19734 & 26.96038 & 38.28162 & 7.560663 \\
\hline 6 & 529575.4 & 34.57116 & 27.15333 & 33.70458 & 4.570933 \\
\hline 7 & 563971.1 & 39.99635 & 25.21072 & 30.54787 & 4.245050 \\
\hline 8 & 600256.5 & 43.20705 & 22.58170 & 29.37689 & 4.834368 \\
\hline 9 & 686487.0 & 39.68255 & 21.52881 & 33.53889 & 5.249756 \\
\hline 10 & 823604.7 & 29.62427 & 24.36896 & 40.18648 & 5.820294 \\
\hline
\end{tabular}


Table 7b: Variance decomposition Graphical Representation
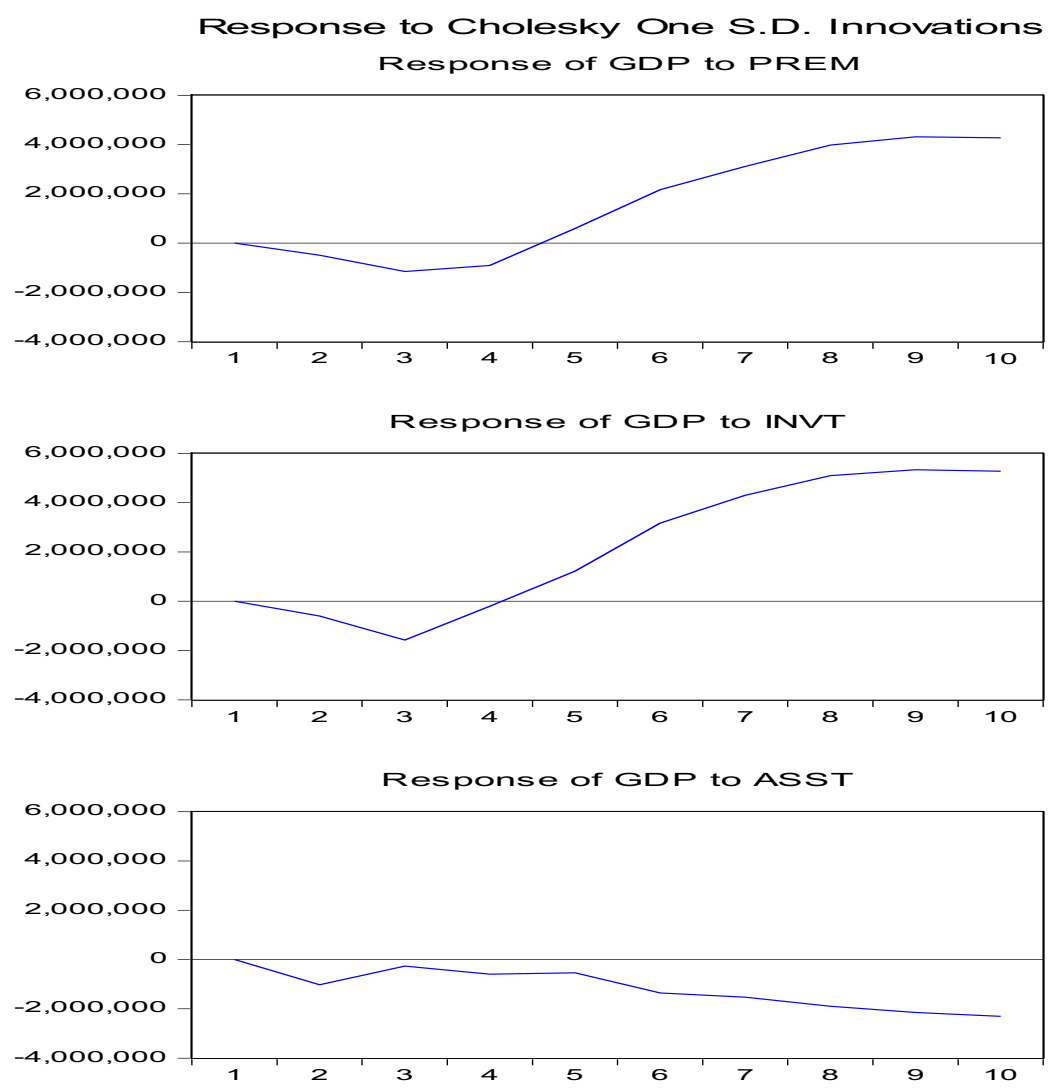

Table 7c: Impulse Response
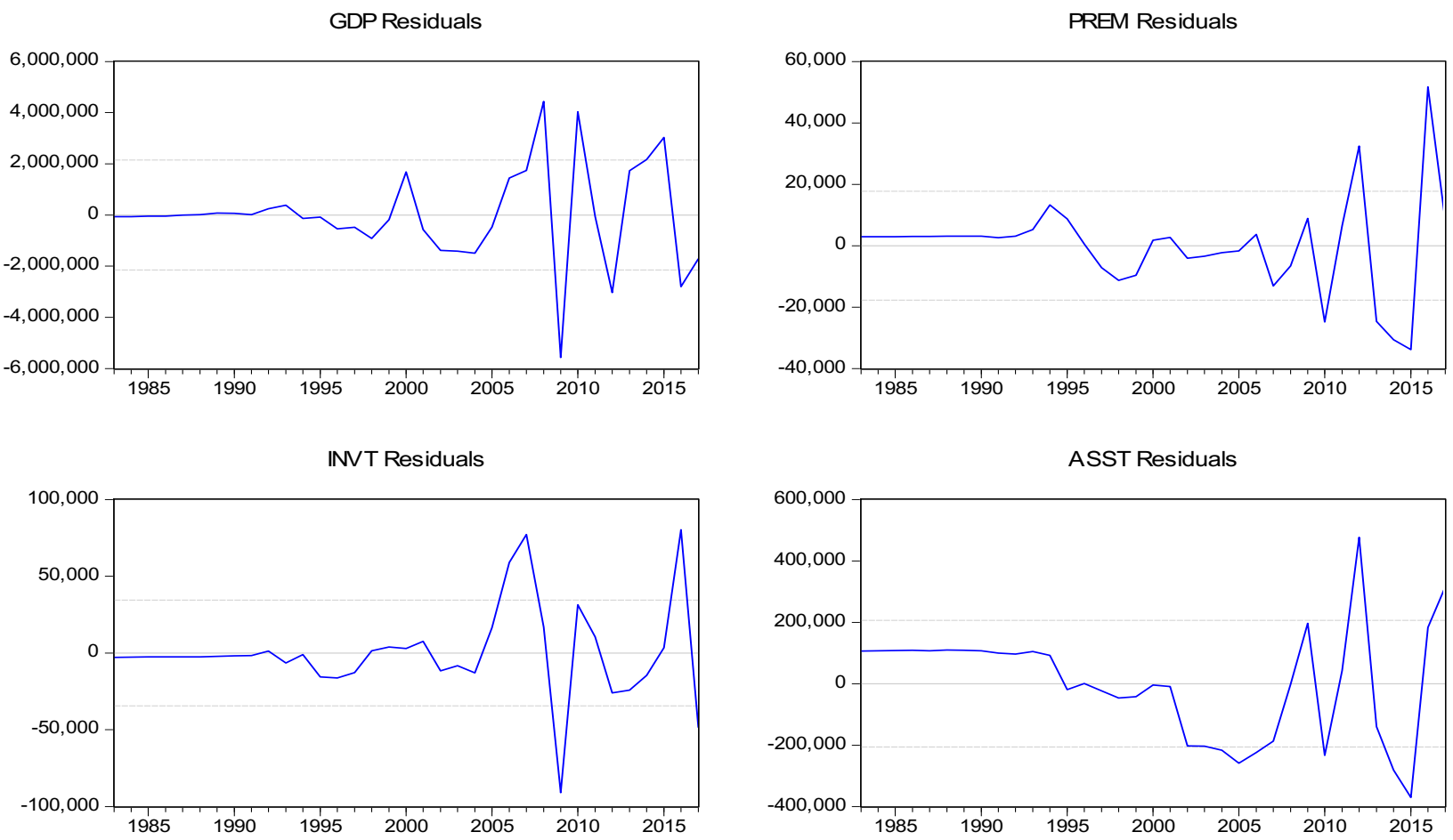

Table $7 \mathrm{a}$ and $7 \mathrm{~b}$ reports Variance Decomposition for 10 period. It can be deduced that the standard error for the various periods is high. Insurance sector investment is more significant than premium for most of the periods as it rose of $5.67 \%$ in period 2 to $49.50 \%$ in period 10 . 
However, since PREMIUM represents revenue for the insurance industry it can be deduced that it has positive impact on GDP for all the periods as it rose from $0.00 \%$ in period 1 to $3.87 \%$ in period 2 before rising to $12.88 \%$ in period 4 . There was further rise to $21.37 \%$ in period 7 and $30.01 \%$ in period 10 . Moreover, INVESTMENT also responds positively to PREMIUM which implies that insurance companies rely on premium to stay in business. It can also be deduced that GDP does not respond significantly to the level of assets of insurance companies. It witnessed constant reduction from $16.72 \%$ in period 2 to $7.85 \%$ in period 9 before rising slightly to $8.35 \%$ in period 10 .

Table 8: Granger Causality Result

Pairwise Granger Causality Tests

Date: 08/21/18 Time: 09:23

Sample: 19812017

Lags: 2

\begin{tabular}{|c|c|c|c|}
\hline Null Hypothesis: & Obs & F-Statistic & Prob. \\
\hline PREM does not Granger Cause GDP & \multirow[t]{2}{*}{35} & 6.75415 & 0.0038 \\
\hline GDP does not Granger Cause PREM & & 9.57550 & 0.0006 \\
\hline INVT does not Granger Cause GDP & \multirow[t]{2}{*}{35} & 32.1068 & 4.E-08 \\
\hline GDP does not Granger Cause INVT & & 6.24190 & 0.0054 \\
\hline ASST does not Granger Cause GDP & \multirow[t]{2}{*}{35} & 0.84583 & 0.4392 \\
\hline GDP does not Granger Cause ASST & & 23.5108 & 7.E-07 \\
\hline
\end{tabular}

\section{Source: Eviews 8}

This granger causality was used test to determine the direction of influence on the variables. The result shows that there is granger causality relationship between insurance premium and GDP which implies that insurance premium influences the direction of economic growth in Nigeria while the growth of the economy also influences growth in insurance premium. From the foregoing, it can e stated that insurance industry relies on the productive capacity of the economy while the economy relies on insurance to keep up business growth. The result also shows that there is granger causality relationship between insurance investment and GDP, that is, a investment influences the outcome of GDP while increase in economic output raises investment decision of insurance companies. Furthermore, there is unidirectional causality relationship between insurance assets and GDP running from GDP to insurance assets.

\section{DISCUSSION OF FINDINGS}

From the analysis carried out, the model was linear in form. Investments of the Insurance industry were negatively related to GDP which does not conform to apriori expectation. This suggests that insurance companies are not investing in long term projects which was decried by NAICOM (2016) and Akpan and Joseph (2017) that insurance companies are into buying and selling like traders not like investors. It has been argued that most insurance industries like their deposit money banks counterparts result in trading of shares, foreign exchange and oil and these was exposed during the global financial crises and fall in oil price where most of their investments were whipped out.

This study finds positive and significant relationship between insurance premium and GDP which therefore conforms to the findings of Mojekwu, Agwuegbo and Olowokudejo (2011) who found a functional relationship between the volume of insurance contribution and economic growth in Nigeria. Oke (2012) also revealed in his study that insurance sector 
growth and development positively and significantly affects economic growth. Eze and Okoye (2013) observed that the insurance premium capital significantly impacted on economic growth in Nigeria and also concluded that a significant positive effect of insurance practice on the growth of Nigerian economy. The implication is that insurance industry have great role to play in mobilizing savings such as premium payment by the insured and should be given more attention by authorities, such attention been given to deposit money banks in terms of regulation and reform.

There was also a positive but less impact of insurance assets and GDP. This supports the findings of Oke (2012) and Torbira \& Ogbulu (2013) who showed that the influence of insurance sector growth had on economic growth was limited because of some cultural, attitudinal traits and values in the economy. Also, Omoke (2011) found a low insurance market activity in Nigeria and that Nigerians have not fully embrace the insurance industry despite its importance to the growth of the economy. It however supports the findings made by Solomon (2018); Ukpong and Acha (2017) whose studies showed a positive link between insurance assets and GDP. The implication is that increasing the assets growth of insurance industry allows them to engage in more investments and savings mobilization through premium. A strong asset based insurance industry can also easily cover claims and provide succour for losses made by the insured.

\section{RECOMMENDATIONS}

From the findings it is necessary for the insurance business authorities to review its reform policy and ensure that policies that will strengthen the functions in premium mobilization in Nigeria. In terms of investment, insurance industry seems to have a place in Nigeria. Insurance companies therefore need to invest more productive sectors of the economy.

\section{References}

Adamu, M. O., Okorafor, U. \& Adeyemi, A. B. (2011). The impact of economic environment on insurance Companies in Nigeria. Journal of Sci. Res. Dev. 13, $11-18$.

Aderibigbe, J. O. (2004). An overview of the Nigeria Financial System. CBN Bullion, 28 (1).

Adeyemi, M. (2005). An overview of the Insurance Act 2003.. In: O. C. Ezekiel, (Ed.), Issues in Merger and Acquisition for the Insurance Industry, 61-78. Proceeding of the NIA workshop on Insurance ACT 2003, Lagos: Nigeria Insurance Association, 2005.

Ahmed, K. R. (2012): Enhancing the value of insurance in Nigeria through paradigm shifts. Journal of Chartered Insurance Institute of Nigeria, 12(3), 16-19.

Ajayi, L. A. (2000), Element and Scope of Insurance, Akure: Hybrid Publishers Limited. ISBN: 978-2858-66-47

Akpan, I. T. \& Joseph, E. M. (2017). Comparative analysis of insurance companies and commercials banks' investment portfolios and economic growth in Nigeria. Arabian Journal of Business and Management Review, 4 (2), 6-25.

Anchanvinay, S. (2008). Insurance a basic need. Retrieved from www.blogRabking.com.

Anderson, F. J. \& Brown, R. L. (2005). Risk and insurance. U.S.A: Society of Actuaries Publications.

Aneke, J.I. (2004). Principles and practice of insurance. Enugu: Tochan Ventures.

Augustine, U. \& Nwanneka, J. M. (2011). Repositioning insurance industry for operational efficiency: The Nigerian case. Journal of Applied Finance \& Banking, vol.1, no.3, 2011, 15-32.

Bencivenga, V. R. \& Smith, B. D. (1991). Financial intermediation and endogenous growth. Review of Economics Studies, 58(2), 195-209.

Brainard, L. (2008). What is the role of insurance in economic development? Retrieved from https://www.draudimas.com/allpics/What_is_the_role_of_economic_developement.pdf

Chang, T., Lee, C.-C., \& Chang, C.-H. (2014). Does insurance activity promote economic growth? Further evidence based on bootstrap panel Granger causality test. The European Journal of Finance, 20(12), 1187-1210. 
Chikeze and Echekoba (2008) Insurance Business and Information Communication Technology; Nigeria Insurance Industry Experience.

Ching, K. S., Kogid, M., \& Furuoka, F. (2010). Causal relation between life insurance funds and economic growth evidence from Malaysia. Asean Economic Bulletin, 27(2), 185-199.

Din, S. M., Abu-Bakar, A. \& Regupathi, A. (2017). Does insurance promote economic growth: A comparative study of developed and emerging/developing economies. Cogent Economics \& Finance (2017), 5:, 1-12.

Din, S. M. U., Angappan, R., \& Baker, A. A. (2017). Insurance effect on economic growth-among economies in various phases of development. Review of International Business and Strategy, 27(4), 409-427.

Eze, O. R. \& Okoye, V. (2013). Analysis of insurance practices and economic growth in Nigeria: using Cointegration Test and error Correction Model. Global Advanced Research Journal of Management and Business Studies, 2(1), 063-070.

Fatula, O. (2007). The imperative of recapitalisation and consolidation in the Nigeria Insurance Industry. I (I\&II), Ikeja Bar Review, p. 128.

Gollier, C. (2003). To insure or not to insure? An insurance puzzle. The Geneva Papers on Risk and Insurance Theory, 28: 5-24.

Goldsmith, R. W. (1969). Financial structure and development. New Haven: Yale University Press.

Greenwood, J., \& Smith, B. (1997). Financial development, growth and the distribution of income. Journal of Political Economy, 98(5), 1076-1107.

Haiss, P., \& Sumegi, K. (2008). The relationship between insurance and economic growth in Europe: A theoretical and empirical analysis. Empirica, 35(4), 405-431.

Irukwu, J. O. (1986). Insurance Year Book. Lagos, Nigeria: Nigerian Reinsurance Corporation.

Jegede, M. I. (2005). A comprehensive analysis of the Insurance Act 2003 and its implications on the insurance business environment - Issues in merger and acquisition for the insurance industry. In: O. C. Ezekiel (Ed.), Proceeding of the NIA Workshop on Insurance ACT 2003, Lagos: Nigerian Insurance Association, 2005, 61-78.

McKinnon, R. I. (1973). Money and capital in economic development. Washington D.C.: Brookings Institution.

Mishkin, F. S. (2010). The economics of money, banking \& financial markets. [9th Edition]. United States: Addison Wesley.

Mojekwu, J., Agwuwgbo, S. \& Olowokudejo, F. (2011). The impact of insurance contributions on economic growth in Nigeria. Journal of Economics and International Finance, 3(7): 444-451.

National Insurance Commission (NAICOM), Nigeria, 2003. http://www.naicom.gov.ng/

NAICOM (2007) Guidelines for the Insurance Sector Reform and Consolidation, Published by National Insurance Commission, Sept. 30, 2005, zone 5, PMB 457, Garki Abuja.

Obaremi, N. (2007). Nigeria insurance special report: big is beautiful. African Business, 4, 51-62.

Obasi, N. (2010). Policies, challenges, reforms and Nigerian disposition to insurance contracts. The Fronteira Post, 1-6.

Oke, M. O. (2012). Insurance sector development and economic growth in Nigeria. African J. Business Management, 6(23), 7016-7023.

Omoke, P. C. (2012). Insurance market activity and economic growth: Evidence from Nigeria. Acta Universitatis DAanubius, 8(2), 34-47.

Osho, L.A, \& Ademuyiwa, M.A. (2017). Insurance and Entrepreneurship Development: Focus on Nigeria. International Journal of Entrepreneurial Development, Education and Science Research, 4 (1), 46-57.

Osunkunle, B. (2002). Impact of insurance in Nigeria. Ibadan: Evans Brothers Publishers.

Pandey, I.M. (2003). Financial management. New Delhi: McGraw Hill Publishers

Salvatore, D. (2013). International economics, (11th Ed.). United States: Fordham University.

Sambasivam, Y., \& Ayele, A. G. (2013). A study on the performance of insurance companies in Ethiopia.

International Journal of Marketing, Financial Services \& Management Research, 2 (7), 138-150.

Schumpeter, J. A. (1911). The theory of economic development. Cambridge, Mass: Harvard University Press. 
Shaw, E. S. (1973). Financial deepening in economic development. New York: Oxford University Press.

Solomon, O. (2018). Insurance premium and investment: what impact has it had on Nigeria's economic growth? www.independent.academia.edu/kingsooloo.

Torbira, L. L. \& Ogbulu, M. O. (2014). Fund mobilization by insurance companies and fixed capital formation: Evidence from the Nigerian economy. International Journal of Financial Research, 5 (2), 69-78.

Ukpong, M. S. \& Acha, I. A. (2017). Insurance and economic development in Nigeria: Co-integration. Scholedge International Journal of Management \& Development, 4 (4), 28-39.

Victor, O. C. (2013). Impact of insurance on economic growth in Nigeria. International Journal of Business and Management Invention, 2 (10), 19-31.

Ward, D., \& Zurbruegg, R. (2000). Does insurance promote economic growth? Evidence from OECD countries. The Journal of Risk and Insurance, 67(4), 489-506.

Zouhaier, H. (2014). Insurance and economic growth. Journal of Economics and Sustainable Development, 5(12), 102-113.

Total Investment, assets and premium of the insurance industry and GDP

\begin{tabular}{|c|c|c|c|c|}
\hline Year & GDP & $\begin{array}{c}\text { Total investment of Insurance } \\
\text { industry }\end{array}$ & $\begin{array}{c}\text { Insurance Industry } \\
\text { Premium }\end{array}$ & $\begin{array}{c}\text { Total asset of } \\
\text { Insurance industry }\end{array}$ \\
\hline 1981 & 94325.02 & 145.453 & 234.05 & 1014.25 \\
\hline 1982 & 101011.23 & 190.389 & 248.77 & 1138.42 \\
\hline 1983 & 110064.03 & 169.496 & 191.80 & 1106.13 \\
\hline 1984 & 116272.18 & 199.519 & 205.69 & 1333.88 \\
\hline 1985 & 134585.59 & 277.681 & 195.29 & 1934.48 \\
\hline 1986 & 134603.32 & 290.626 & 254.16 & 2487.99 \\
\hline 1987 & 193126.20 & 324.225 & 406.50 & 2651.50 \\
\hline 1988 & 263294.46 & 326.049 & 486.65 & 4255.90 \\
\hline 1989 & 382261.49 & 414.653 & 673.09 & 5290.83 \\
\hline 1990 & 472648.75 & 498.160 & 1013.67 & 6333.74 \\
\hline 1991 & 545672.41 & 987.437 & 1296.24 & 6628.38 \\
\hline 1992 & 875342.52 & 5094.023 & 2445.69 & 10166.73 \\
\hline 1993 & 1089679.72 & $2,078.444$ & 4931.92 & 20329.96 \\
\hline 1994 & 1399703.22 & 1817.680 & 14519.15 & 23220.86 \\
\hline 1995 & 2907358.18 & 4232.125 & 13525.13 & 17155.20 \\
\hline 1996 & 4032300.34 & 12379.46 & 11091.33 & 15276.92 \\
\hline 1997 & 4189249.77 & 13613.08 & 10941.58 & 20079.63 \\
\hline 1998 & 3989450.28 & 15656.88 & 11688.25 & 22578.89 \\
\hline 1999 & 4679212.05 & 21583.46 & 14597.28 & 50131.65 \\
\hline 2000 & 6713574.84 & 25192.64 & 22531.46 & 61600.00 \\
\hline 2001 & 6895198.33 & 32157.27 & 28981.29 & 78060.48 \\
\hline 2002 & 7795758.35 & 36940.87 & 37765.89 & 85255.73 \\
\hline 2003 & 9913518.19 & 54642.84 & 43441.81 & 124267.37 \\
\hline 2004 & 11411066.91 & 74590.75 & 50100.83 & 141222.03 \\
\hline 2005 & 14610881.45 & 121844.22 & 67465.56 & 203113.12 \\
\hline 2006 & 18564594.73 & 216359.91 & 81583.75 & 307542.61 \\
\hline 2007 & 20657317.67 & 329247.93 & 89104.89 & 427497.16 \\
\hline 2008 & 24296329.29 & 336491.38 & 126470.30 & 573154.46 \\
\hline 2009 & 24794238.66 & 148083.88 & 153127.12 & 586459.54 \\
\hline 2010 & 54204795.12 & 100239.95 & 157336.81 & 585015.79 \\
\hline 2011 & 63258579.00 & 103573.1 & 175756.75 & 621095.14 \\
\hline 2012 & 71186534.89 & 106384.456 & $366,657.8$ & 3150089.60 \\
\hline 2013 & 80222128.32 & 133915.194 & $119,652.4$ & 4058087.31 \\
\hline 2014 & 89043615.26 & 245002.634 & 288478.3 & 3840077.06 \\
\hline 2015 & 94144960.45 & 266171.959 & 332664.1 & 5302879.35 \\
\hline 2016 & 101489492.20 & 394819.591 & 377932.77 & 6158947.80 \\
\hline 2017 & 113719048.23 & 547982.940 & 400687.22 & 7515351.41 \\
\hline
\end{tabular}

Source: CBN statistical Bulletin Various Issues 